\title{
Pre-Commitment in contemporary constitution making? African and Kenyan experiences reviewed
}

\author{
By Dan Juma, Harvard*
}

\section{Introduction}

In almost every nation, extraordinary political events such as independence, regime change, secession or cessation of occupation are often followed by constitution making or some form of constitutional change. ${ }^{1}$ In these contexts, constitutional change serves constitutive, structural and normative functions, ranging from establishing an identity, ${ }^{2}$ to structuring power ${ }^{3}$ and transforming society. ${ }^{4}$ Other functions of the enterprise include political and cultural engineering, ${ }^{5}$ guaranteeing human rights ${ }^{6}$ and legitimating government. ${ }^{7}$ In view of

* Dan Juma, The author is currently a doctoral candidate at Harvard Law School. He worked at the Constitution Review Commission between 2001-2005 in different capacities. E-Mail: djuma@ sjd.law.harvard.edu

The author is grateful to Professor Mark Tushnet and Dean Martha Minow, Harvard Law School for reading and commenting on drafts of this paper. Similar gratitude is extended to participants of the Harvard Law School Winter Writing Workshop convened by Mr. Jorge Gonzalez in March 2011. The usual caveats apply.

1 Louis Aucoin/Laurel E Miller (eds.), Framing of the State in Times of Transition: Case Studies in Constitution Making, Washington, D.C. 2010, Jon Elster, Forces and Mechanisms in the Constitution-Making Process, Duke Law Journal 45 (1995), p. 364, Bruce Ackerman, We The People, Cambridge, Mass. 1993, Keith Banting/Richard Simeon (eds.), The Politics of Constitutional Change in Industrial Nations, London 1985 and Edward McWhinney, Constitution Making: Principles, Process, Practice, Toronto 1981.

2 See for example Michel Rosenfeld, The Identity of the Constitutional Subject: Selfhood, Citizenship, Culture and Community, London 2010 and Issa Shivji (ed.), State and Constitutionalism: An African Debate on Democracy, Harare 1991.

See for example Ivo D. Duchacek, Power Maps: Comparative Politics of Constitutions, Santa Barbara, Calif. 1973.

See for example Henk Botha et al (eds.), Rights and Democracy in a Transformative Constitution, Stellenbosch 2003.

See for example Andrew Reynolds (ed.), The Architecture of Democracy: Constitutional Design, Conflict Management, and Democracy, Oxford 2002.

6

See for example Dawid van Wyk et al (eds.), Rights and Constitutionalism: The New South African Legal Order, Kenwyn 1994.

7 See for example Hastings W.O. Okoth-Ogendo, The Quest for Constitutional Government, in: Goran Hyden et al (eds), African Perspectives on Government, Trenton, NJ 2000, p. 48-49, Walter F. Murphy, Constitutions, Constitutionalism and Democracy, in: Douglas Greenberg et al (eds.), Constitutionalism and Democracy: Transitions in the Contemporary World, New York 1993, p. 8, Banting/Simeon, note 1, p. 7 and McWhinney, note 1, p. 9 and 23 (describing 'symbolic' or 
these and entrenched nature of a constitution, it is not surprising, therefore, that constitution making remains one of the most highly contested, emotional, sometimes conflicted political exercises. ${ }^{8}$

History and contemporary experience purvey different forms and models of constitution making. Some forms of constitution making are incremental, whereas in some polities, constitution making is undertaken at a historic moment through a specially mandated body that is typically the seat for negotiations and adoption of the text of the new constitution, with or without direct public approval. ${ }^{9}$ The common stages of constitution making include agenda setting, public consultation, deliberation, drafting, mobilization, adoption, ratification and promulgation, whereas conventional avenues through which these have been undertaken include constituent or constitutional assemblies, constitutional conventions, national conferences, executive committees, constitutional commissions, expert committees, parliaments and referenda. ${ }^{10}$ While each of these has different implications, sometimes variations between them exist only in nomenclature.

The choice of the method of constitution making is dependent on a confluence of factors. At a general level, incumbents and other contending parties often prefer avenues conducive to their desired outcomes, aware that the final substance of constitution making depends on the process. ${ }^{11}$ Each of these groups may also seek favorable timing for this purpose, because of its significance on the outcomes. ${ }^{12}$ In the typical model, the political elites agree on the process, but only after some political skirmishes or compromises. This paper examines the paradoxes and problems of constitution making, primarily, self-dealing and obstruction by incumbent governments and political parties, and the structuring of

'nominal' constitutions, "designed more for public relations at home or abroad than as a genuinely operational legal charter.").

See, for example Calvin C. Jillson, Constitution Making: Conflict and Consensus in the Federal Convention of 1787, New York 1988 and Daniel Elazar, Constitution Making: The PreEminently Political Act, in: Banting/Simeon, note 1, p. 232

See McWhinney, note 1, p. 27-41, Banting/Simeon, note 1, p18, Andrew Arato, Forms of Constitution Making and Theories of Democracy, Cardozo Law Review 17 (1995), p. 191, John Elster, Constitution Making in Eastern Europe: Rebuilding the Boat in the Open Sea, Public Administration Review 71 (1993), p. 169 and Patrick Fafard/Darrel Robert Reid, Constituent Assemblies: A Comparative Survey, Institute of Intergovernmental Relations, Research Paper No. 30 (1991). See also Willy Mutunga, The Principal Mechanisms of Constitution-Making, in: Goran Hyden/Denis Venter (eds.), Constitution-Making and Democratization in Africa, Pretoria 2001, p. 143.

McWhinney, note 1, p. 27 (stating that "[t]he choice among these different options may be made casually or inadvertently, but it will never be value-neutral in its consequences. What looks like a simple, technical, machinery choice may in fact predetermine or influence the final substantive recommendations as to the content and direction of a new, or 'renewed,' constitutional system. The evidence would suggest that governments are very often aware of this truth, and shape their choice of the instruments of constitution-making accordingly.")

12 See generally Vicki C. Jackson, What's in a Name? Reflections on Timing, Naming, and Constitution-making, William \& Mary Law Review 49 (2008), p. 1249. 
constitution making to deal with these challenges. While recognizing that the design or form of constitution making and its outcomes are often influenced by a set of complex factors, the paper examines whether constitutional pre-commitment, ${ }^{13}$ that is, the binding of constitution makers through self-binding devices, may be used to deal with these problems of constitution making. The basic question here is, can the idea of constitutional pre-commitment, associated with constitutions in force, be applied to constitutions in the making?

The South African and Kenyan constitution making processes, two of Africa's recent constitution making processes, will be the points of reference. South Africa's experience is apposite for its unique transition, in which the existing regime conceded to change against the background of demands entrenched in the form of justiciable, binding constitutional principles in the Interim Constitution of 1993. Kenya's constitution making process, which occurred in two main phases between $2000-2005$ and $2008-2010,{ }^{14}$ is relevant for its design of constitution making in sequential stages, and the use of relatively weaker, nonentrenched normative principles enshrined as 'objectives' of constitutional change. In both the South African and Kenyan cases, specialized constitutional courts were established; in the former, with a broader constitutional mandate including certification of the constitutional text to ensure compliance with the constitutional principles, and in the latter, with a mandate only to arbitrate over disputes relating to the process only.

Constitution making is by its nature a highly complex process with various dynamics at play. This paper is limited in that it targets only a specific aspect- pre-commitment. Moreover, it does not purport to draw any causality between pre-commitment and the success or otherwise of both processes. In exploring the task at hand, the paper's aim therefore is to illuminate questions for further debate. First, what is constitutional precommitment, and who are its subjects? Second, what is the intersection, if any, between constitution making and pre-commitment? In other words, is pre-commitment applicable only to constitutions in force, or constitutions in the making as well? In constitution making, who makes such pre-commitment? Third, but relatedly, does the claim that constitution making engenders higher lawmaking hold in recent constitution making, or is selfdealing a problem inherent in the process? Can pre-commitment devices deal with these problems?

See Jon Elster, Ulysses Unbound, Cambridge 2000, Stephen Holmes, Pre-commitment and the Paradox of Democracy, in: Jon Elster/Rune Slagstad (eds.), Constitutionalism and Democracy, Cambridge 1988, p. 195, Jon Elster, Ulysses and the Sirens: Studies in Rationality and Irrationality, Cambridge 1979, Stephen Holmes, Passions and Constraints: On the Theory of Liberal Democracy, Chicago 1995.

The second phase between 2008 and 2010 was not contemplated ex ante in the design of the process, but instead resulted from the failure of the first phase, and the continued clamor for constitutional change. Failure here is used to refer to the non-adoption of a new constitution at the close of the process, notwithstanding the other successes that the process may have produced in the short and long terms such as legitimating the vernacular of constitutionalism and democratization. See Jennifer Widner, Constitution Writing in Post Conflict Settings: An Overview, William \& Mary Law Review 49 (2008), p. 1515. 


\section{Paradoxes of Constitution Making}

Constitution making is founded on its promise to transform, reinterpret and reimagine a polity. However, the complexities of social, political and economic transformation enact a chasm between such idealism and reality, disrupting a constitution's promise to perform these functions. Constitution making may thus ultimately undermine the very values that society seeks to promote; it may engender a backlash. This should not be surprising, since constitutions per se do not guarantee constitutionality. ${ }^{15}$ Similarly, the imposing presence of the paradox of "constitutions without constitutionalism"16 in contemporary constitutional thought also illuminates the limits of constitutions. These paradoxes replay in the process of constitution making, a few of which stand out in particular. ${ }^{17}$

The first of these has been termed the "paradox of the founding." 18 The question here relates to whether there is an existing democratic, constitutional or legal mandate in constitution making. ${ }^{19}$ In other words, where is the repository of the new constitution's validity, and who should determine the grundnorm, ${ }^{20}$ or pre-legal, meta-legal norms otherwise termed the "prior constitutional question"? ${ }^{21}$ This question seems abstract at first glance, yet it acquires significance where constitution making is undertaken under an undemocratic constitution sought to be repudiated. The paradox here is, since the flawed undemocratic constitution is part of the problem that the constitution making process is initiated to remedy, why should it be respected? ${ }^{22}$ Should there be alternative sources of constitutionality, legality, validity or even legitimacy?

See for example, Jeffrey K. Tulis/Stephen Macedo, The limits of constitutional democracy, Princeton 2010.

H.W.O Okoth-Ogendo, Constitutions without Constitutionalism: Reflections on an African Political Paradox, in: Greenberg, note 7, p. 65.

The author is grateful to Dean Martha Minow for pointing him to, and framing some of the following issues. See E-mail to author (Mar. 15, 2011, 11:38 EST) (on file with author).

See Kevin Olson, Paradoxes of Constitutional Democracy, American Journal of Political Science 51 (2007), p. 330.

Id. See also Frank I. Michelman, Constitutional Authorship, in: Larry Alexander (ed.), Constitutionalism: Philosophical Foundations, Cambridge 1998, p. 64.

20 See Hans Kelsen, Pure Theory of Law (Max Knight trans., Berkeley 1967), p. 3-23. For a problematization of this theory, including its circularity problems or "infinite regress", see Michelman, note 19, p. 72 .

22 Rephrasing Elster, note 1, p. 375 (stating that "[a]lmost by definition, the old regime is part of the problem that a constituent assembly is convened to solve. There would be no need to have an assembly if the regime was not flawed. But if it is flawed, why should the assembly respect its instructions?") 
It has been claimed that constitution making "processes are seldom neutral [as they] privilege some kinds of interests and weaken others." 23 The second paradox therefore relates to balancing these interests in constitution making. The typical constitution making process has at least two protagonists - the power holders or other controlling party capable of capturing, scuttling, obstructing or even derailing the process in pursuit of short-term or partisan interests on the one hand, ${ }^{24}$ and the demandeurs on the other hand, characterized usually as the public spirited. ${ }^{25}$ Constitution making may also actuate a clash between the majority and a minority. For example, a minority may demand constitutional change, but the majority may coalesce to resist the minority's claims. ${ }^{26}$ Similarly, a majority's demands for change may be frustrated by a minority through a veto or denial of its consent, where required. ${ }^{27}$ While these are an oversimplification of the complexities of constitutional change, they illustrate the puzzle of balancing competing interests of various groups and the almost indissoluble reach of politics in constitutional change. ${ }^{28}$

Another paradox lies in the questions, why, when and how should constitution making be undertaken? It may be assumed that demand for constitutional change is driven by knowledge of, if not consensus on the premises and scope of the new order, yet such consensus or knowledge is often elusive. Instead, some constitution making processes have elicited political conflict, ${ }^{29}$ whereas their outcomes may be unsettled or clothed in ambigu-

Banting /Simeon, note 1 at p. 6.

See Jackson, note 11, p. 1252 and Elster, note 1, p. 377. Elster identifies different types of interests, including personal interest, group interest and institutional interests. See also Elster, note 9, p. 182 (explaining that the interest of political parties and of political institutions is "especially evident in the design of electoral laws, whether these are part of the constitution or not. Small parties tend to be in favor of proportional representation, preferably with a low threshold (if any), whereas large parties argue for majority voting in single-member districts...A party that has a strong presidential candidate will push for a strong presidency in the constitution, whereas others will want to limit his powers...The interest of political institutions appears most clearly when the institutions to be regulated by the constitution also take part in the constitution-making process...A constitution written by a legislative assembly may be expected to give large, perhaps excessive powers to the legislature.") (references omitted.)

See generally Vivien Hart, Constitution Making and the Right to Take Part in a Public Affair, in: Aucoin/Miller, note 1, p.20, 34 and Banting/Simeon, note 1, p. 10.

Banting/Simeon, note 1, p. 12.

Jackson, note 11, p. 1252

See for example, Mark Tushnet, Some Scepticism about Normative Constitutional Advice, William \& Mary Law Review 49 (2008), p. 1473 (discussing the triumph of politics over normative advice in constitution making).

See for example Faisal Amin Rasoul al-Istrabadi, A Constitution Without Constitutionalism: Reflections on Iraq's Failed Constitution Making Process, Texas Law Review 87 (2009), p. 1627, Widner, note 14, Kirsti Samuels, Post-Conflict Peace-Building and Constitution-Making, Chicago Journal of International Law 6 (2006), p. 663 and Betty Kaari Murungi, 2005 Cardozo International Advocate for Peace Award: Acceptance Speech, Cardozo Journal of Conflict Resolution 7 
ity. ${ }^{30}$ More vexing but related is the issue of timing constitution making. In some cases, interim constitutions have been adopted as a temporary solution, pending appropriate timing or agreement on substantive issues, ${ }^{31}$ whereas in some, timing as well as the content of constitution making has been imposed by external forces. ${ }^{32}$

The above paradoxes and challenges have seen the evolution of various mechanisms and approaches of constitutional change, with varied results. ${ }^{33}$ Thus, incremental reform or gradualism may address the pathologies of constitution making in a polity, yet lead to paralysis in another nation. Multi-level stages of constitution making, or an interim constitution may also be suitable in one country, yet unsuitable for others. In some countries, constitution makers may be barred from participating in constitutional politics in the immediate years after a new constitution as a means of managing self-interest, whereas in some, such a mechanism may not be acceptable. Constitutional pre-commitment, an additional device, offers an important means of managing these difficulties.

\section{Pre-commitment in Constitution Making?}

In liberal political thought, the function of a constitution is to define governmental power in a polity. ${ }^{34}$ In this thin form, a constitution thus articulates fundamental normative values and institutional arrangements through which society pursues its vision; its essence is to bind the future to these precepts. ${ }^{35}$ In a nutshell, a constitution embodies constitutionalism, that is, the imposition of limits on government, adherence to the rule of law and protection

(2005), p. 352 (noting Kenya's divisive constitutional debate and constitution making process, which produced and escalated conflict in the country in 2005.)

See for example, Rosenfeld, note 2, p. 141 (discussing the role of ambiguity in the success of Spain's constitution making process between 1977 and 1978.)

See Andrew Arato, Redeeming the Still Redeemable: Post Sovereign Constitution Making, International Journal of Politics, Culture and Society 22 (2009), p. 430 (stating that one mode of "postsovereign" constitution making relies on two drafting stages, with " two constitutions, an interim and a final one, where the rules of the first constrain the making of the second", Jackson, note 11, p. 1252 (explaining that "transitional" constitutions may seem to offer important solutions") and McWhinney, note 1, p. 44

See Jackson, note 12, p. 1264 (referring to the constitutions of Japan, Germany and Iraq) and McWhinney, note 1, pp. 22- 25 and 62-64 (describing the influence of the colonial powers in the timing of postcolonial constitutions and occupying powers in Japan.) See also Andrew Arato, Post-Sovereign Constitution-Making and Its Pathology in Iraq, New York Law School Law Review 51 (2007), p. 535 and Noah Feldman, Imposed Constitutionalism, Connecticut Law Review 37 (2005), p. 857.

33 See Widner, note 14 (providing data analyses on each of these issues.)

Geoffrey R. Stone et al (6th edn.), Constitutional Law, Aspen 2009, p. 1-2.

Id. 
of fundamental rights. ${ }^{36}$ However, not all constitutions engender constitutionalism, nor is a written constitution a prerequisite for constitutionalism. ${ }^{37}$

The debate on constitutional pre-commitment evokes the traditional debate on the mutual relationship as well as tension between constitutionalism and democracy. ${ }^{38}$ The debate revolves around institutional design in a constitutional democracy, particularly judicial review of legislation. ${ }^{39}$ It is not profitable to rehearse these normative contestations over constitutional and democratic theory here, but some outlines are in order. On one hand, arguments have been arraigned that judicial review preserves a polity's values regardless of generations or prevailing democratic sentiments, ${ }^{40}$ guarantees the preconditions for democracy by securing fundamental rights and freedoms necessary for the political process, ${ }^{41}$ performs the function of "representation-reinforcement" by bridging the deficits of elective democracy, ${ }^{42}$ and acts as a democratic preservative by preventing pathologies of majoritarianism which may lead to self-destruction. ${ }^{43}$ On the other hand, hand it has been posited that judicial review of legislation is undemocratic by disenfranchising the people ${ }^{44}$ and taking away the right to democratic self-determination. ${ }^{45}$ Yet another charge is that

36

See Alexander, note 19, p. 5.

Id. See also Stone et al, note 34, p. 2 and Louis Henkin, Constitutionalism, Democracy and Foreign Affairs, New York 1990.

For example, a constitution guarantees the preconditions for democracy, for example by securing fundamental rights and freedoms necessary for the political process Stone et al, note 34, p. 44 and Cass Sunstein, Constitutionalism and Secession, University of Chicago Law Review 58 (1991), p. 637 (citing the right to freedom of speech and the right to vote as other familiar illustrations). For the tensions, see the following discussion.

See for example, Mark Tushnet, Weak Courts, Strong Rights: Judicial Review and Social Welfare Rights in Comparative Constitutional Law, Princeton 2008.

See generally Ronald Dworkin, Freedoms Law, Cambridge 1996, Ronald Dworkin, A Matter of Principle, Cambridge 1985 and Ronald Dworkin, Taking Rights Seriously Cambridge 1977. See also Holmes, note 13, p. 197 (discussing the mutual supportiveness of constitutionalism and democracy and Thomas Jefferson's and James Madison's contributions to the debates). See also Stone et al, note 38 , p. 49.

41 Stone et al, supra note 38 at p. 44 and Sunstein, id, p. 637 (citing the right to freedom of speech and the right to vote as familiar illustrations).

See John Hart Ely, Democracy and Distrust: A Theory of Judicial Review, Cambridge 1980, p. 7.

See for example, Sunstein, note 38, p. 637 (stating that " $[\mathrm{t}]$ he precommitment strategy permits the people to protect democratic processes against their own potential excesses or misjudgments") and Holmes, note 13, p. 218- 226 (discussing examples of scenarios and pathologies, absent strict constitutional constraints, such as frivolous amendments in lieu of democratic deliberation and potential interregna).

Jeremy Waldron, The Core of the Case Against Judicial Review, Yale Law Journal 115 (2006), p. 1346, Larry D. Kramer, The People Themselves: Popular Constitutionalism and Judicial Review, Oxford 2004 and Mark Tushnet, Taking the Constitution Away from the Courts, Princeton 1999.

Jeremy Waldron, Law and Disagreement, Oxford 2001. 
judicial review poses a "counter-majoritarian difficulty" to the elected branches of government. $^{46}$

These arguments reflect contestations over the idea of constitutional pre-commitment. Consistent with pre-commitment theorizing, a constitution is a device or strategy for selfbinding or constraining others, created by a polity as a constraint against its own excesses. The premise for pre-commitment is that constitutional norms (such as human rights, for instance) are higher values and should therefore be insulated from the dictates and passions of the normal political process. ${ }^{48}$ Given that future actions may not be fully rational due to "preference changes," "interest adjustments," "momentary passions," "myopia" or "weakness of will," pre-commitments are instituted to bind the future. ${ }^{49}$ An assumption inherent in this idea is that constitutional pre-commitments are made in moments of tranquility and sobriety, to prevent harm to self and others on future occasions when actors are subdued by imperfectly rationality, sub-rationality, or irrationality. ${ }^{50}$

The assumptions underlying constitutional pre-commitment remain contested. In essence, the arguments and counter arguments replicate the preceding debate on constitutionalism and democracy, and need not be transposed here. ${ }^{51}$ Here, as in the preceding discussion, the claims revolve around the legitimacy, justifiability and effectiveness of precommitment. First, constitutional pre-commitment theorists privilege constituting generations, while underestimating the wisdom of future generations. ${ }^{52}$ Second, given that constitutions are typically adopted by a majority, and sometimes opposed by a minority, precommitment binds the minority as well, ${ }^{53}$ thus bringing dialogue or compromise between these groups to closure. Third, pre-commitments per se do not ensure rationality of decision makers. Finally, constitutional pre-commitments, like constitutions, are not omni-

Alexander Bickel, The Least Dangerous Branch: The Supreme Court at the Bar of Politics, New Haven 1962, p. 16.

Elster, note 13, p. 88, 89, Sunstein, note 38, p. 641, Holmes, note 13 and Friedrich Hayek, The

48 Constitution of Liberty, Chicago 1960, p. 176- 192.

Elster, note 13, p. 90-91.

49

Id and Jon Elster, Don't Burn Your Bridge Before You Come To It: Some Ambiguities and Complexities of Precommitment, Texas Law Review (2003), p. 1765.

51

See for example Andrés Palacios Lleras, The Indeterminate Side of Constitutions as Precommitment Strategies (Apr. 4, 2011), http://works.bepress.com/andres_palacios_lleras/6 and Carl Lebeck, Pre-commitments, Disagreement and the Limits of Constitutionalism, Scandinavian Studies in Law 48 (2005), p. 133.

53

Elster, note 50, p. 1758. 
potent in their binding function, ${ }^{54}$ nor is constitutionalism devoid of normative shortcomings. 55

These critiques of constitutional pre-commitment notwithstanding, constitutions, even without constitutionalism, matter. ${ }^{56}$ Similarly, pre-commitments which underwrite a constitution are also as important, even if not always controlling. But the application of precommitment to constitution making invites the question of its temporal scope. In other words, when is the genesis of constitutional pre-commitment? Take a hypothetical case of a constitution making process in country $X$ that begins with the inauguration of a selfselected constituent assembly in year 1 , followed by a popular ratification at the end of year 2 , and promulgation of the constitution in year 3. Assume further that the constituent assembly was preceded by some form of self-determination or declaration of sovereignty by the people of country $X$, with open public debates on its political, social and economic future. In this hypothetical, when could it be deemed that the people of country $X$ have precommitted as a polity?

While political or legal theorizing may purvey various outcomes to this question, its answer could be mounted in the context of the emerging constitutional norms in the constitution making process. Additionally, resort may be had to empirically examining the extent to which constitution makers were bound by their source of authority. In this mode, an argument may be erected that constitutional pre-commitment extends back, and is therefore applicable to the process of constitution making, where such is rooted in preexisting normative as well as procedural constraints. ${ }^{57}$ The essence of this argument is that constitution makers are not "unbound binders"; 58 they are bound by their mandates or at least influenced by the sovereign act of constitution making, and pre-existing norms in the form of pre-constitutional rules and meta-constitutional principles. ${ }^{59}$ This claim is not new; past constitutional framers have pre-committed themselves against passion and interest through among others, special rules of procedure; ${ }^{60}$ whether or not they succeeded in self-

Elster, note 13, p. 94 (noting that "constitutions may not bind after all.")

See generally Neil Walker, The Idea of Constitutional Pluralism, Modern Law Review 65 (2002), p. 319 (discussing critiques of modern constitutionalism), Martin Loughlin/Petra Dobner (eds.), The Twilight of Constitutionalism? London, 2010 and Martin Loughlin/Neil Walker (eds.), The Paradox of Constitutionalism, London 2007.

Okoth-Ogendo, note 7, p. 36-37 and Henkin, note 37, p. 6.

For a discussion of such norms generally, see for example Larry Alexander/Frederick Schauer, On Extrajudicial Constitutional Interpretation, Harvard Law Review 110 (1997), 1359 and Richard S. Kay, Preconstitutional Rules, Ohio State Law Journal 42 (1981), p. 187.

Holmes, note 13, p. 223- 225.

See Elster, note 13, p. 100- 174 and Elster, note 1, p. 373 (stating that there are "upstream" and "downstream" constraints, the former imposed on the constitution making body and the latter created by the need for ratification of the document produced by the constitution making body).

See for example Holmes, note 13, p. 140 (stating that "the American and French framers precommitted themselves against the temptations of passion and interest.") 
binding is a different enterprise. ${ }^{61}$ Additionally, this claim of pre-commitment's applicability to constitution making can be supported by the 'permanence' of constitutional change due to the adaptive nature of constitutional law. ${ }^{62}$

The linking of pre-commitment to constitution making is not an attempt to provide causal explanations of why specific constitutional choices are made. Instead, it explains, albeit incompletely, how they are made. The former is the province of theories of constitutional design, bountiful in the law and economics and political science domains. ${ }^{63}$ In the next part, typologies of pre-commitment devices in Table $\mathbf{1}$ below are adopted to discuss the constitution making paradoxes and contests in South Africa and Kenya. The list is by no means exhaustive, but the approach is to examine constitution making mechanisms as pre-commitment devices, using the typologies offered below.

\section{Table 1}

\begin{tabular}{ccc}
\hline Devices for Pre-commitment & Reasons for Pre-commitment & Constitution making Devices \\
\hline Eliminating/Including Options & Overcome Passion & Normative/Irreducible Minima \\
Imposing Costs & Overcome Self-interest & Public Participation \\
Creating Delays & Overcome Strategic Time & Transitional Constitutionalism \\
Inconsistency & \\
Changing Preferences & Neutralize/Prevent Preference & Multi-Level Stages \\
Change & Veto/Ratification \\
Investing in Bargaining Power & Ensure Efficiency & Transitional Provisioning \\
Inducing Ignorance & Overcome Self-interest & Entrenched Supermajorities \\
Requiring Supermajorities & Overcome Frivolity & Entrenched Roadmaps \\
Timing Clauses & Overcome Indecision &
\end{tabular}

Sources: Elster 1979, 1995, 2000, 2003

61

62

See Louis Michael Seidman, Our Unsettled Constitution: A New Defense of Constitutionalism and Judicial Review, New Haven 2001 and Michael Foley, The Silence of Constitutions: Gaps, "Abeyances", Temperament and the Maintenance of Government, London 1989, p. 61 (arguing that the unwritten part of a constitution is its most significant element because it accommodates the Constitution's encoded system of abeyances by which any constitution ultimately survives or perishes.)

63 See for example Rodger D. Congleton/Birgitta Swedenborg (eds.), Democratic Constitutional Design and Public Policy: Analysis and Evidence, Cambridge, 2006, Dennis Mueller, Constitutional Democracy, Oxford 1996 and James M. Buchanan and Gordon Tullock, The Calculus of Consent: Logical Foundations of Democracy, Ann Arbor 1962. 
The arguments can be cast as follows. Pre-commitment devices such eliminating options from the set of feasible constitutional choices, for example, can be used to constrain the constitution maker by foreclosing debate on the isolated issues, while also enabling decision making from within the circumscribed set of options. ${ }^{64}$ A veil of ignorance may be induced, by decoupling constitution makers from discerning or partaking in the benefits and costs of their constitutional choices. ${ }^{65}$ This may be achieved through "prospectivity" where choices are made without knowing the identities of its winners or losers; "generality," where rules are chosen to govern all irrespective of interest; "durability," where choices are expected to obtain in the remote future; and "randomization," where choices are made without regard to expected outcomes. ${ }^{66}$ Cooling-off and delays in the constitution making process or the application of certain rules may also prevent emotions or hasty decisions or facilitate transitional arrangements. ${ }^{67}$ In a nutshell, different forms of these devices or strategies may be used in the constitution making process - each with varying degrees of success - depending on context, to achieve equivalent results as will be shown by examination of South African and Kenyan processes.

There are three basic questions underlying the Table above, and this paper in generalFirst, why should the idea of pre-commitment in constitution making not be analyzed in simpler vernacular, say, as "sequential negotiations"? 68 At first glance, it appears that the stark similarities between negotiation theories and practices and the pre-commitment devices itemized above may support such labelling. For example, the "elimination of options" may be viewed as a "narrowing of issues," whereas the "creation of delays" may be characterized as a "cooling- off" tactic, both typical in negotiations. This applies also to the "closure rule" that prohibits reopening agreed issues, as well as principle-based agreement and 'bracketing' of disputed issues for future resolution during negotiations.

The pre-commitment framework deployed may be displaced by other analytics and functional equivalents reflective of, but not necessarily coterminous with precommitment. Thus, in addition to the negotiation analytic suggested above, which is itself a framework underwritten by complex theories and practices, ${ }^{69}$ the constitution making processes may

64

65

66

67

68

69

Elster, note 50, p. 1754.

See generally Adrian Vermeule, Veil of Ignorance Rules in Constitutional Law, Yale Law Journal 111 (2001), p. 399. For a critique, see Arato, note 9, p. 223- 230.

Id.

Id.

The term "sequential negotiations" is borrowed from Mark Tushnet. The author is grateful to him for pointing this issue out, and framing the ensuing issues. See E-mail to author (Mar. 21, 2011, 20:06 EST) (on file with author). This part relies on this discussion.

For the tactics, stages and theoretical foundations of negotiation, see generally Robert Mnookin, Bargaining with the Devil: When to Negotiate, When to Fight New York, 2010, G. Richard Shell, Bargaining for Advantage: Negotiation Strategies for Reasonable People (2nd edn.), New York 2006 Robert H. Mnookin et al, Beyond Winning: Negotiating to Create Value in Deals and Dis- 
also be examined from a decision analysis optic, ${ }^{70}$ transition theory, ${ }^{71}$ or a "procedural predecision" analytic. ${ }^{72}$ In short, while these and other analytics are equal in dignity and may be used to study these processes, they each have their implications. As it emerges in the following part, South Africa's historic constitutional transition was uniquely structured and facilitated in part by pre-commitment, as was some aspects of the Kenyan process. Yet this analytic has hardly been deployed to study these processes.

The second question relates to the process of pre-committing. How do parties arrive at these pre-commitments when they cannot arrive at the substantive commitments to be embodied in the constitution? ${ }^{73}$ In other words, given the assumption that constitutional pre-commitment works because of the ambiguity or uncertainty about the constitution's ultimate outcomes, what technologies enable pre-commitment here where the parties can almost foresee the outcomes of their pre-commitments in the ensuing constitution making process? Similarly, assuming that there is a level of certainty on what the parties are precommitting to before constitution making, should they not leapfrog directly to framing the constitution's substance?

The analysis here turns on the anatomy of constitutional pre-commitment. By its nature, constitutional pre-commitment is premised on the notion that it is a bond, not bondage. ${ }^{74}$ Through pre-commitments ambiguity, adaptability and endurance over time, a range of constitutional choices may be maintained under constitutional pre-commitment. This applies to pre-commitment in constitution making. Thus, despite the proximity between the act of pre-commitment, and the making of the constitution itself, there is often a level of uncertainty and ambiguity due to ignorance and changing preferences as events unfold. In South Africa, for example, while the binding constitutional principles were intended at assuring the parties, their outcomes could not be predicted. The Constitutional Court's rejection of the first constitutional text illustrates this - even the Constitutional Assembly, despite the elaborate nature of the Interim Constitution of South Africa, was uncertain as to the specific constitutional choices ordained by the Constitutional Principles, only adopted less than a half a year before.

putes, Cambridge 2000) and Roger Fisher et al, Getting to Yes: Negotiating Agreement Without Giving In (2nd edn.), Boston, 1991.

70 See for example, David E. Bell et al (eds.), Decision Making: Descriptive, Normative and Prescriptive Interactions, New York 1988.

71 See for example, David Ginsburg, The Democratization of South Africa: Transition Theory Tested, Transformation 74 (1996), p. 29.

Waldron, note 45, p. 291 (recharacterizing Elster's pre-commitment as a form of "procedural predecision.")

The author is grateful to Professor Mark Tushnet for pointing this, and framing the following issues and questions. See E-mail to author (Mar. 21, 2011, 20:06 EST) (on file with author).

Holmes, note 13 at p. 215. 
The final question relates to the baseline problem, that is, the undistorted 'neutral' or 'objective' or 'rational' form of constitution making. This question acquires salience given the paper's claim that pre-commitment devices may be used to eliminate or manage selfinterest and biases in constitution making. While important, it is not profitable to pursue the answer to this question in this paper. It serves our purposes instead to identify some key forms of self-interest, each of which shapes constitution making. These include personal interest, that is, the individual interest of constitution makers in specific constitutional choices; group interest, that is, the interests of social, political and economic formations; and institutional interest, that is, entrenchment by a participating body of advantageous constitution choices. $^{75}$

\section{Pre-commitment in South African and Kenyan Constitution Making?}

\section{A. The Context of South African Constitution Making}

It was stated above that the South African constitution making process, while unique in its origins and design, provides important insights on pre-commitment in fundamental constitutional change. Although South Africa's is a long and complicated history with important antecedents, the release of Nelson Mandela in February 1990 was the watershed in its transition. ${ }^{76}$ At this juncture, the question was not whether or when, but rather how the transition would take place. However, the method of transition and its outcomes were uncertain. A remarkable feature of the negotiations was the series of agreements and commitments made by the parties, although these were often dishonored. The first of these negotiations was in May 1990, when the African National Congress (ANC) and the National Party (NP)/Government signed the Groote Schuur Minute, undertaking to begin formal negotiations. ${ }^{77}$ These negotiations, termed 'talks about talks,' were aimed at setting the stage for real negotiations and a smooth transition to democracy. ${ }^{78}$ The parties reached further agreement in August 1990, termed the Pretoria Minute, on the release of political prisoners and the suspension of ANC's armed actions. ${ }^{79}$

75

See Elster, note 1.

See Synnøve Skjelten, A People's Constitution: Public Participation in the South African Constitution-making Process, Midrand 2006. p. 18, Richard Spitz/Matthew Chaskalson, The politics of Transition: A Hidden History of South Africa's Negotiated Settlement, Oxford 2000, p. xi , Hassen Ebrahim, The Soul of a Nation: Constitution Making in South Africa, Oxford 1998, Siri Gloppen, South Africa: The Battle over the Constitution, Aldershot 1997, Steven Friedman, The Long Journey: South Africa's Quest for a Negotiated Settlement, Braamfontein 1993 and Allister Sparks, Tomorrow is Another Country, Sandton 1995 for a discussion of the South African transition.

See text in Ebrahim, note 76, p. 483.

Ebrahim, note 76, p. 83.

Spitz/Chaskalson, note 76, p. 16 and Ebrahim, note 76, p. 61. 
The locus of South Africa's democratic transition was a series of commitments and agreements between the two main negotiating parties, the ANC and the (NP)/Government. The outcome of the transition reflected South Africa's unique political and socio-economic history, as did the choice of institutions for constitution making. In particular, South Africa used several stages of constitution making, including the involvement of a newly elected legislature (acting as the Constitutional Assembly), subject to a set of "constitutional principles," expert input, public participation, and certification by the Constitutional Court. While this design and the success of the South African constitution making process was the function of a set of diverse factors at play including the rising costs of apartheid, its linchpin was its embeddedness in pre-commitment through a set of binding principles entrenched in the Interim Constitution, and a Constitutional Court to police compliance through the certification process.

Consistent with historical experience and the realities of the time, the interests implicated in the South African transition heightened the stakes, with negotiations on constitutional change stretching over a year. The ANC urged majority rule and an interim government, ${ }^{80}$ opposing the NP/Government's proposal for consociational democracy, based on compulsory power sharing, minority veto and a rotational presidency. ${ }^{81}$ Some of these proposals bore remarkable ironies; for example, the NP/Government's proposal for power sharing was mocked as a "discovery" of these tenets "only when the power was about to slip through their hands. $" 82$ In terms of the process of constitution making, the ANC proposed a popularly elected constituent assembly, whereas the NP/Government and the Inkatha Freedom Party (IFP) advocated for "constitutional continuity," elite-driven, multi-party convention and expert panel, since each of them would be a minority party in an elected assembly. ${ }^{84}$ After protracted debates, punctuated by violence,

80

81

82

83

84

Ebrahim, note 76, pp. 58 and 113.

See Heinz Klug, The Constitution of South Africa: A Contextual Analysis, Oxford 2010, p. 16, 32.

Gloppen, note 76, p. 92. See also Spitz/ Chaskalson, note 76, p. 27 (narrating NP/Government's proposal for an upper legislative chamber, in which the "same number of seats would be allocated to parties gaining over 10 per cent of the vote, regardless of their level of support, [and thereby] over-represent minority parties and entrench paralysis in the political system- a loser takes all position") and Sparks, note 76, p. 12, 13 (narrating the NP's opposition to black-majority rule and clamor for consensus-based power-sharing government structure, a proposal mocked as a "loser keeps all" plan.)

The NP/Government urged "constitutional continuity," by proposing that agreements be enacted under the provisions of the 1983 Constitution, an approach which would effectively vest the NP/Government dominated Parliament the role of approving the new Constitution. The contradiction here is that this Constitution was considered undemocratic - the NP/Government itself made no pretense when it ruled out a non-racial election until a new Constitution allowed a legal basis for universal adult franchise. See $K l u g$, note 81, p. 49.

Klug, note 81, p. 48-49 (narrating that the NP/Government preferred a "elite pact-making process" among 'recognized' contenting parties, whereas the IFP claimed that an elected constituent 
the ANC thus made another advance in January 1991 by proposing a compromise, which the NP/Government conceded to due to the reputational costs, international sanctions and pressure from domestic and transnational constituencies - "an all-party congress to negotiate the route to a constituent assembly [as] the body which would draft a new constitution." 85 Further, in response to the recurrent violence, political parties, trade unions and local administrations signed the National Peace Accord in September $1991 .{ }^{86}$

The National Peace Accord set the stage for a multi-party Convention for a Democratic South Africa (CODESA), which convened in December 1991 at Kempton Park. ${ }^{87}$ The CODESA was mandated to transform the 'talks' into 'substantive' negotiations on a new constitutional order. ${ }^{88}$ At the outset, the 228 participants representing nineteen political parties and organizations signed a Declaration of Intent, under which the parties committed to an "undivided South Africa, the separation of powers, and a Bill of Rights." 89 However, the Declaration was underwritten by deep divisions, most conspicuously between the ANC and the NP/Government. These differences also implicated the parties understanding of the CODESA's mandate. ${ }^{90}$

Democratic transitions often raise conundrums of sequencing, legitimacy and accountability. In South Africa, the CODESA faced the following dilemmas. First, could it make substantive decisions on the future constitution without a democratic, let alone legal mandate? Could its decisions be the basis of a democratic constitution, if it was itself not constituted democratically? With an undemocratic Constitution, how could the ruling elite's call for constitutional continuity be the alternative? ${ }^{91}$ Here, a circularity problem arises, since it is may not be logically possible to eliminate elements of "non-democracy prior to the democratic procedures." ${ }^{92}$ But this does not eliminate the question, as did in South Africa: where did CODESA's accountability vest? Would the negotiating parties, as interested players, deliberate disinterestedly or if not, how would self-dealing be prevented?

These questions animated the disagreements between the parties in South Africa. Insisting on its support for an interim government and an elected constitution making body, the

assembly was undemocratic, unless a mechanism was provided for minorities to "give their prior assent") and Skjelten, note 76, p. 20, 21.

Ebrahim, note 76, p. 89.

Ebrahim, note 76, p. 97.

Spitz/ Chaskalson, note 76, p. 19, 20, Ebrahim, note 76, p. 98 and Gloppen, note 76, p. 201.

Spitz/ Chaskalson, note 76, p. 19

Id.

Skjelten, note 76, p. 18 (stating that the 1983 Constitution perpetuated the apartheid system), Ebrahim, note 76, p. 18 and Hugh Corder, Towards a South African Constitution, Modern Law Review 57 (1994), p. 493 (explaining that the 1983 Constitution was "intended finally to close the door on African participation in central government in South Africa.")

Arato, note 9, p. 192. 
ANC maintained that the forum should "determine as little as possible because, [since] as the likely majority party, [it] would be well placed to shape the new order mode or less as it pleased after elections." 93 The ANC reiterated that the CODESA was beset by accountability, democratic and legitimacy deficits, and that its function was to establish enough 'common ground' for constitution making. ${ }^{94}$ In contrast, the NP/Government rejected majoritarian constitution making, as did other political parties, ${ }^{95}$ and instead sought to control and prolong the transition. It thus preferred that the CODESA makes substantive decisions as much as possible so as to guarantee it a key role in shaping the constitutional future. ${ }^{96}$ In the wake of the all-white referendum of March 1992, which "confirmed that the majority of white people were in favor of a negotiated settlement," 97 the NP/Government began to move towards the ANC's proposal for an interim government and a democratically elected forum to make the new constitution, on the basis of an interim constitution drafted by the CODESA, provided that the forum would be all-inclusive and consensus based. ${ }^{98}$ This became the broad outlines of the roadmap for constitutional change in South Africa.

\section{B. The Context of Kenyan Constitution Making}

In contrast, Kenya did not experience any major extraordinary political event in its history before it began its constitution making process. ${ }^{99}$ However, despite the gulf between the histories of the two countries, constitution making in Kenya between 2000 and 2010 provides some important parallels and contrasts with the South African process. ${ }^{100}$ In Kenya, the clamor for constitutional reform in Kenya had antecedents in the normative foundations of the independence Constitution of 1963 and its subsequent manipulation. ${ }^{101}$ In essence, the independence Constitution was a compromise between the political elites on issues as

\footnotetext{
93

Id.

94 Id.

95 Spitz/ Chaskalson, note 76, p. 21, 71.

96 Klug, note 81, Spitz/ Chaskalson, note 76, pp. 24, 48 and Sparks, note 76, p. 128.

97 Ebrahim, note 76, p. 110.

98 Id. See also Ebrahim, note 76, p. 105.

99 but see infra note peace.

100 For a review of the process of constitution making, see Eric Kramon/Daniel N. Posner, Kenya's New Constitution, Journal of Democracy 22 (2011), p. 89, Jill Cottrell/Yash Ghai, Constitution Making and Democratization in Kenya (2000-2005), Democratization 14 (2007), p. 1 and Alicia L. Bannon, Designing a Constitution-Drafting Process: Lessons from Kenya, Yale Law Journal 101 116 (2007), p. 1824.

See generally Yash P. Ghai/J.P.W.B McAuslan, Public Law and Political Change in Kenya, Nairobi 1970 and Hastings W.O. Okoth-Ogendo, The Politics of Constitutional Change in Kenya Since Independence, 1963-1969, African Affairs 71 (1972), p. 9.
} 
vexing as land. ${ }^{102}$ Second, and relatedly, the independence Constitution's shortcoming was its focus on exercise of power than power transformation, and thus became a legitimation instrument. ${ }^{103}$ Thus, norms such as fundamental rights were written into the law "not as minimum prescriptions of justice and good government, but as limitations on governmental power." "104 Their foundation lay in a perverted form of limited government and checks and balances -implicit in the 'Westminster parliamentary model' upon which the Constitution was founded. In reality, these safeguards were not worth the paper they were written as illustrated by the series of constitutional amendments and regressive politics that followed.

Third, the independence Constitution represented remarkable continuities with the colonial system. ${ }^{105}$ This should not be surprising, since post-colonial arrangements elsewhere were generally derivative of the institutions of the colonial power involved. Thus, in addition to adopting the Westminster model, another overhang was the primacy given to the political organization and culture reminiscent of the colonial period, thus impeding possible alternatives in political mobilization and culture. ${ }^{106}$ Economically, whereas the constitution had aspects of devolution, it was grafted on a centralized ideology. The state thus became, as it did to the colonial elites, an instrument of class rule and self-enrichment. ${ }^{107}$ Even more drastic was the preservation of the colonial legal order, especially administrative law. ${ }^{108}$ Finally, the Constitution fell short of reinventing the social system, social will and social glue, which had been brutally disrupted by colonialism. ${ }^{109}$

See generally Smokin Wanjala, Essays on Land Law: The Reform Debate in Kenya, Nairobi 2000, Calestous Juma/J.B. Ojwang, In Land We Trust: Environment, Private Property and Constitutional Change, Nairobi 1996 and H.W.O. Okoth-Ogendo, Tenants of the Crown: Evolution of Agrarian Law and Institutions, Nairobi 1991.

Okoth-Ogendo, note 7, p. 45 and Okoth-Ogendo, note 101, p. 9.

105

Okoth-Ogendo, note 101, p. 9.

Nic Cheeseman, Political Linkage and Political Space in the Era of Decolonization, Africa Today 53 (2006), p. 3 Okoth-Ogendo, supra note 16, p. 71 and Ghai/McAuslan, note 101, p. 220.

See for example, Okoth-Ogendo, note 101, p. 10-11 (stating that "[i]n political organization and expression, Kenya has been remarkably lacking in innovation and has remained loyal to the patterns of organizational behavior and the political values of the later part of the colonial period.")

Jennifer A Widner, The Rise of a Party-State in Kenya: From Harambee to Nyayo! Berkeley 1992, Yash Ghai, The Theory of the State in the Third World and the Problem of Constitutionalism, Connecticut Journal of International Law 6 (1991), p. 411 and Okoth-Ogendo, note 16, p. 71 (stating that the African elites tracked the ways of the colonial elites' use of state institutions which had enabled them to "convert the "national" economy" into some kind of private estate.")

This is not a suggestion that a reversion to the pre-colonial order was required, or even feasible. See Marius Pieterse, Traditional African Jurisprudence, in Christopher Roederer/Darrel Moellendorf (eds.), Jurisprudence, Lansdowne 2000, p. 439 (stating that "[t]he notion that pre-colonial African society contains numerous well hidden universal 'truths' which, once prospected and polished, would enrich the dull worldview of the West with their unsophisticated wisdom is an 
These pathologies subverted the independence Constitution, and in the years following, a litany of formal amendments ensued, fundamentally altering the Constitution. In the first six years alone, Parliament enacted about ten amendments aimed at strengthening the executive or the ruling party at the expense of the people's sovereignty. ${ }^{110}$ A key feature of these and subsequent amendments was the pruning of constitutional safeguards, laying ground for political excesses. For example, the Constitution retained a parliamentary executive system, with the executive drawn from, and dominant in Parliament. ${ }^{111}$ Another amendment linked the term of the President to Parliament, so that a vote of no confidence in the government would repudiate not only the executive its tenure, but also the National Assembly. ${ }^{112}$ In 1982, an amendment made Kenya a de jure one-party state. Yet another amendment stripped judges of security of tenure in the late $1980 \mathrm{~s} .{ }^{113}$

In an attempt to reverse these developments and restore constitutional democracy, the clamor for constitutional reform began towards the end of 1960s. In the 1970s and 1980s, the ruling elite frustrated calls for constitutional change, imposing huge political costs on advocates of change. However, in the late 1980s and the early 1990s, local and international forces gave an impetus to reform, but with minimal results. Thus in 1991 under intense pressure, the Constitution was amended to provide for political pluralism. These amendments did not however cure the deficits of the Constitution, and advocates for change continued the clamor for reform. ${ }^{114}$

The assumption that incumbents generally prefer the use of normal channels of law making so as to control the agenda for constitutional change found a seat in the Kenyan process. ${ }^{115}$ This was the genesis of the limited constitutional reforms initiated in the 1990s and the contest over the process of constitution making, with the ruling party favoring a parliamentary, expert driven process in which it would be over-represented, and the opposition and civil society advocating a people driven process, based on public participa-

attractive one, and one that African and Western scholars are often equally keen to embrace. Yet, this notion fails to overcome the ideological bias standing in the way of meaningful engagement with African society.") (Footnotes omitted).

111 See Okoth-Ogendo, note 101, p. 21-33.

11 Jacton B. Ojwang, Constitutional Development in Kenya: Institutional Adaptation and Social Change, Nairobi 1990, p. 228- 231.

Jacton B. Ojwang, Constitutional Trends in Africa - The Kenya Case, Transnational Law \& Contemporary Problems 10 (2000), p. 524.

113 See generally Makau Mutua, Justice Under Siege: The Rule of Law and Judicial Subservience in Kenya, Human Rights Quarterly 23 (2001), p. 96.

See Makau Mutua, Kenya's Quest for Democracy: Taming Leviathan, Boulder 2008, p. 108, Godwin R. Murunga and Shadrack W. Nasong'o (eds.), Kenya: The Struggle for Democracy, London 2007 and Willy Mutunga, Constitution-making from the middle: Civil society and transition politics in Kenya, $1992-1997$, Nairobi 1999. Civil society is used here to denote non-govern115 mental, religious and professional groups and political pressure groups.

Banting/Simeon, note 1 at p. 17. 
tion. ${ }^{116}$ After protracted struggles and attempts by the ruling elite to deflect the clamor for reform through minimum constitutional changes, the path towards constitutional reform was finally laid in 1997, when a Statute was enacted to facilitate comprehensive constitution making by the people of Kenya. ${ }^{117}$

Disputes over this legislation arrested further developments for over two years, including the appointment of the Constitution Review Commission to undertake the drafting of the new constitution. ${ }^{118}$ In the second half of 2000 , a bi-partisan parliamentary committee jumpstarted the process by appointing the Constitution Review Commission, which was now rivaled by a parallel, civil society led People's Commission of Kenya. ${ }^{119}$ In the first half of 2001, following negotiations, these two Commissions were 'merged' by law so as to deescalate political conflict. ${ }^{120}$ The Constitution Review Commission, the main organ mandated to conduct civic education and draft the constitution, would comprise constitutional experts "with knowledge of and experience in matters relating to law and public affairs," subject to regional and gender equity. ${ }^{121}$ The Commission was further mandated to convene a National Constitutional Conference in later stages. ${ }^{122}$ With the coming into force of the amendments, the stage had finally been set for constitution making after almost four years since the enactment of the initial Review Act.

\section{A. Pre-commitment through Constitutional Entrenchment}

Apart from its other normative functions, constitutional entrenchment of the roadmap, procedures and timing of constitutional change can be an important pre-commitment device. Therefore, the centerpiece of South Africa's constitution making process was the entrenchment of procedures for making the final constitution in the Interim Constitution. The circumstances of this choice, which are outlined elsewhere and need not be discussed here, ${ }^{123}$ provide important parallels with the Kenyan constitution making process. As outlined above, the first phase of constitution making in Kenya was non-entrenched, as it was

116 Mutua, note 114, p. 99 and Mutunga, note 114.

117 The Constitution of Kenya Review Act (No. 13 of 1997), hereinafter the Review Act, as amended or reenacted between 1998-2009.

See Constitution of Kenya Review Commission, Final Report, Nairobi 2005, p. 39 (hereinafter CKRC Report) and Republic of Kenya, Report of the Parliamentary Select Committee Reviewing the Constitution of Kenya Review Act, 1997, Nairobi 2000, p. 4 (hereinafter PSC Report).

120

PSC Report, note 118, p. 4-9 and CKRC Report, note 118, p. 39.

See CKRC Report, note 118, p. 39.

121 Sections 7- 9 of the Constitution of Kenya Review Act (Cap 3A of 2001).

122 Despite the agreement, differences over the nature of the Conference reemerged in later stages of constitution making, with a faction of the government and sections of civil society asserting that the Conference was undemocratic, and only a Constituent Assembly would be appropriate to the task. See generally Mutua, note 118 and Mutunga, note 118.

See notes 80-98, and accompanying text. 
anchored under ordinary statute- the Review Act. ${ }^{124}$ This requirement for entrenchment found justification in the following grounds. First, it was claimed that absent such entrenchment, the process was unconstitutional since the Constitution of Kenya had no express provision in its text contemplating its replacement. ${ }^{125}$ Adherents of this approach also claimed that no institution, not even the people, could purport to engage in an exercise of making a new Constitution, unless such had legal validity through entrenchment in the existing Constitution of Kenya. Second, an argument was put forward that given the historical coupling of constitution making with extraordinary political events, and the absence of such a "constitutional moment," constitution making was unlikely to be successful unless constitutionally safeguarded. ${ }^{126}$ Finally, the historical ambivalence of the political class towards reform and the uncertainties of the impending political transition required that the political elite binds itself or is bound by some strong constraints in the form of constitutional entrenchment. ${ }^{127}$ These claims were not without merit. The absence of constitutional entrenchment exposed the entire constitution making process to political subterfuge, manipulation and even potential annulment by the High Court under its judicial review or constitutional review powers. In the end, the omission to constitutionally entrench the first phase of the Kenyan constitution making process was perhaps its very tipping point. ${ }^{128}$

125 Constitution of Kenya (Revised Edition 2001). Under section 47(1), the Constitution provided that "[s]ubject to this section, Parliament may alter this Constitution."

This claim was based on a misreading of Bruce Ackerman's idea of "constitutional moments" as well as related theories that couple constitutional change with extra-ordinary events. See generally, Bruce Ackerman, We The People: Transformations, Cambridge 2000, p. 5, 7 and 87 and Peter H. Russell, Constitutional odyssey: Can Canadians become a Sovereign People? (3d edn.), Toronto 2004, p. 106 (claiming that "[n]o liberal democratic state has accomplished comprehensive constitutional change outside the context of some cataclysmic situation such as revolution, world war, the withdrawal of empire, civil war, or the threat of imminent breakup...") and McWhinney, note 1 , p. 15 (stating that "...the element of national popular support as a necessary pre-condition for codification [of] constitutional law- almost invariably occurs in or immediately after a period of great public excitement and resultant public euphoria when it is relatively easy to build, and retain for sufficiency of time to enable codification, a certain climate of popular political consensus. These periods normally occur during and after great political crises..."). But see also Sujit Choudhry, Ackerman's higher lawmaking in comparative constitutional perspective: Constitutional moments as constitutional failures? International Journal of Constitutional Law 6 (2008), p. 193 and Mark Tushnet, Potentially Misleading Metaphors in Comparative Constitutionalism: Moments and Enthusiasm, Jean Monnet Working Paper 5/04 (April 5, 2011), http://centers.law. nyu.edu/jeanmonnet/papers/04/040501-04.pdf and in relation to extraordinary events, Elster, note 1, p. 370 (stating that while new constitutions are almost always written in the wake of political or economic crises or exceptional circumstance of some sort, exceptions abound.) See Bannon, note 100, p. 1849.

Law Society of Kenya, Standing Committee on Constitutional Review Final Report to the LSK Council, Nairobi 2006. 
In contrast, the second phase of constitution making that followed the African Union mediated National Peace Accord that followed the political crisis in Kenya in 2008 was entrenched in the Constitution of Kenya. ${ }^{129}$ The Constitution was amended to entrench the "sovereign right" of the people to replace the Constitution "through a referendum,", "with time limits within which specific activities, decisions and stages had to be undertaken. Additionally, the Constitution of Kenya Review Act ${ }^{131}$ was enacted to provide the framework for completing the constitution making process. This statute established the Committee of Experts, as the technical arm to solicit public views on the contentious issues in the existing draft constitutions and write a draft constitution, ${ }^{132}$ a Parliamentary Select Committee as the political consensus-building arm, and a ratifying referendum. In sum, while it could not be claimed that the success of the second phase was the function of the entrenchment of the roadmap, procedures and timing, it no doubt forestalled political posturing and filibustering in the second phase of constitution making. ${ }^{133}$

The supermajority rule is yet another pre-commitment device whose effectiveness in Kenya depended on constitutional entrenchment. Broadly, a supermajority rule is a mechanism or norm through which a past (or current) majority restricts the range of current (or future) options in order to enhance such options' long-run utility. ${ }^{134}$ Such rules may also improve consensus building as it provides incentives for compromise, given that no single group can easily enact its preferred choices. While this device was used effectively in the second phase of Kenyan constitution making process due to its entrenchment in the Con-

129

Section 47A (1) of the Constitution of Kenya (Amendment) Act (No. 10 of 2008) and Section $60 \mathrm{~A}$ of the Constitution of Kenya (Amendment) Act (No. 10 of 2008).

Section 47A (1) of the Constitution of Kenya (Amendment) Act (No. 10 of 2008).

132

Constitution of Kenya Review Act (No. 9 of 2008).

Sections 29 and 30(1) of the Constitution of Kenya Review Act (No. 9 of 2008) mandated the Committee of Experts to study all existing draft constitutions prepared by the Review Commission (2002) and the National Constitutional Conference (2004), the Proposed New Constitution (2005) and documents reflecting political agreement on critical constitutional questions. These provisions presumed that issues that were not contentious in these constitutions had been agreed upon, and therefore, closed.

The reopening of issues and filibustering had been one of the problems in the first phase of constitution making, especially at the National Constitutional Conference. See National Constitutional Conference, Rapporteur General's Report I and II, Nairobi 2003, paras. 9, 45 (stating that there had been deliberate filibustering and diversionary discourses in some Technical Working Committees, and that some had engineered stalemates and protracted debate through filibustering over very minor issues). In the second phase, the restriction of debate provided a mechanism for foreclosing reopening of agreed issues or filibustering' on non-essential issues which were not otherwise contentious during the debates almost spanning a decade. See Committee of Experts, Report of the Committee of Experts on Constitutional Review, Issued on the Submission of the Proposed Constitution of Kenya 23 February 2010, hereinafter COE Report, at pp. 6-7 (Apr. 4, 2011), http://www.coekenya.go.ke. William \& Mary Law Review 40 (2008), p. 365. 
stitution, ${ }^{135}$ the rule did not work in the first phase. In the wake of political skirmishes between two factions over the Draft Constitution adopted by the National Constitutional Conference, one of these political sects amended the law in Parliament to remove such requirement, ${ }^{136}$ thereby easing the introduction of changes in the Draft Constitution before the referendum. In the new phase of constitution making, this loophole was managed through a constitutionally entrenched supermajority rule, requiring votes of not less than sixty-five per cent of all the members of the National Assembly in order to change the Draft Constitution submitted by the Committee of Experts.

\section{B. Pre-commitment through Constitutional/Normative Principles}

Disagreement on the appropriate pathway towards constitutional change reflects the divergences of interests and visions on the nature of the system of governance under the new constitution. Even more, disagreements often mirror suspicions between the negotiating parties. In South Africa, the minority parties were wary that the ANC would control the ensuing constitution making process. ${ }^{137}$ A solution therefore lay in balancing the competing interests of the negotiating parties and their constituencies by formatting the future through binding constitutional principles. In September 1992, following three months of stalled negotiations punctuated by violence, labor strikes, mass protests and massacres, the ANC and the NP/Government signed a Record of Understanding to resume negotiations, ${ }^{138}$ under which a democratically elected body would draft a new constitution within a fixed time frame. ${ }^{139}$ The parties further agreed that there would be an interim government of national unity, with the constitution making body acting as the interim Parliament. The transitional government and the constitution making body would function within an interim constitution, which would also be the basis of conducting South Africa's first democratic elections, to be negotiated by a multi-party forum. Finally, a fundamental pillar of the

Section 47A(2)(b) of the Constitution of Kenya (Revised Edition 2009)provided that "when a draft Constitution proposing the replacement of this Constitution has been introduced into the National Assembly, no alteration shall be made in it unless such alteration is supported by the votes of not less than sixty-five per cent of all the members of the Assembly (excluding the ex officio members)."

Section 28 of the Constitution of Kenya Review Act (Cap 3A Laws of Kenya 2001) required that the Attorney-General publishes the draft Constitution adopted by the National Constitutional Conference (as revised by the Review Commission following a referendum) for tabling before the National Assembly for enactment within seven days. Ironically, this provision was part of the outcome of the amendments to the law in 2001, pursuant to which the constitution making process finally received the confidence of the factions that had hitherto differed on the process.

Spitz/Chaskalson, note 76, p. 25.

138 Spitz/Chaskalson, note 76, p. 29 and Ebrahim, note 76, p. 140.

139 Klug, note 81, p. 28, 51 (noting that the agreement reflected the NP/Government's insistence on continuity and the ANC's preference for change) and Spitz/ Chaskalson, note 76, p. 30. 
agreement required that the interim constitution embeds a set of principles to bind the constitution making body. ${ }^{140}$

In Kenya, all organs of constitution making were bound by normative principles enshrined in the law guiding the process. ${ }^{141}$ Unlike South Africa, ${ }^{142}$ however, these normative principles were not entrenched in the form of constitutional principles. However, like in South Africa, the principles were the product of elite negotiations that had prefaced the commencement of the formal constitution making process. Although hortatory, the law also provided another set of process-related principles, which required the constitution making organs to be accountable to the people of Kenya, uphold national interest and ensure that the outcome of the review process faithfully reflects the wishes of the people of Kenya. ${ }^{143}$ However, these principles did not safeguard the integrity and success of the constitution making process, especially in the phase between 2000 and 2005. The National Assembly, for example, subordinated public views and altered the Draft Constitution assembled by the Review Commission and the National Constitutional Conference. Quite apart from the shortcomings in terms of their design and constitution, ${ }^{144}$ the latter two bodies (as well as the Committee of Experts), these bodies were beset by accusations of partisanship. ${ }^{145}$

What explains the flight to principles in South Africa and Kenya? In South Africa, it may be speculated that the principles were a means of eliminating and including constitutional options in the new constitution as follows. These principles ensured that the areas of broad agreement were recorded as such. ${ }^{146}$ Following the experience with the negotiations

140 The principles, included as Schedule 4 of the Interim Constitution of South Africa, were negotiated and finalized at the Multi-party Negotiating Process (MPNP) between May and November 1993. Schedule 4, as amended subsequently, incorporated a list of thirty four Constitutional Principles which were not hortatory, but instead binding on the Constitutional Assembly and the Constitutional Court in its certification of the final text. Their uniqueness lay in their breath and generality, but also their ability to substantively limit the Constitutional Assembly since they could not be amended. See Skjelten, note 76, p. 21, Spitz/ Chaskalson, note 76, p. 78, Sparks, note 76, p. 105 and Francois Venter, Requirements for a New Constitutional Text: The Imperatives of the Constitutional Principles, South African Law Journal 112 (1995), p. 32.

141

Sections 4 and 6 of the Constitution of Kenya Review (Act No. 9 of 2008), termed the "Objects and purpose of Constitutional review" and the "Guiding principles" respectively, as well as sections 3 and 5 respectively of the Constitution of Kenya Review Act (Cap 3A of 2001).

142 See note 140 and accompanying text.

143 Section 5 of the Constitution of Kenya Review Act (Cap 3A of 2001) and section 6 of the Constitution of Kenya Review (Act No. 9 of 2008).

144 It appears that the trinity of an expert Commission, National Constitutional Conference and National Assembly in the first phase provided perverse incentives and institutional paths for sabotaging constitution making. See Yash Ghai, The Role of Constituent Assemblies in Constitution Making (April 5, 2011).

See for example, Mutua, note 118, p. 124.

146 See for example, Jackson, note 12, p. 1282 (referring to the Constitutional Principles as "a form of partial, long-term entrenchment [or] prebinding efforts") and Johann Kriegler, The Constitutional 
at the CODESA, the parties were aware that abstract general principles may facilitate agreement, ${ }^{147}$ notwithstanding the disagreements and the diverging positions. Such agreement on the broad principles would also signal a commitment to, or promise of a settlement. Second, the principles were connected to the design of the constitution making process, and as such facilitated agreement on the roadmap to a new constitution. ${ }^{148}$ The link here is that constitutional principles were considered a normative constraint on future constitution makers, assuring the negotiating parties that their interests would be safeguarded. ${ }^{149}$ Given that a transition of power to the majority was imminent, the NP/Government and other parties invoked constitutional principles as a guarantee for minorities. ${ }^{150}$ However, the ANC also secured its bargain under the deal, since the other parties also conceded to a democratically elected constitution making body, bound by broad based constitutional principles. 151

These arguments may be applied to the constitution making process in Kenya. However, such comparison is disrupted by the differences in the weaker juridical status of the normative principles in Kenya's constitution making. Although key constitution making actors such as the Constitution Review Commission and the Committee of Experts stated in their reports that they were bound by these principles, ${ }^{152}$ it remains speculative whether they were symbolic or had a legally binding effect in the end. It can be stated, however, that as the normative minima or irreducible elements with which the new constitution had to comply, these principles cast a shadow on the range of possible constitutional choices available to constitution makers. This explains why the shifting design preferences of actors

Court of South Africa, Cornell International Law Journal 36 (2003-2004), p. 361 (providing a background of the Principles in the commercial practice common in complex corporate mergers, where the agreed principles of the merger are recorded up front but the detail is left to be filled in later.) See also Marinus Wiechers, Namibia: The 1982 Constitutional Principles and Their Legal 147 Significance, South African Yearbook of International Law 15 (1989-1990), p. 20.

148 Bertus De Villiers, Birth of a Constitution, Kenwyn, 1994, p. 37.

48 Spitz/Chaskalson, note 76, p. 415.

149 Spitz/ Chaskalson, note 76, p. 71, 78 (explaining that some parties such as "The DP had a fairly clear sense that after elections it would have a negligible number of elected representatives in a constitution making body. For this reason it was eager to maximize the effect of the Kempton Park process, in which a small party could have an influence far out of proportion to its electoral support. The DP joined the consensus behind Constitutional Principles... In this way, Constitutional Principles would prolong the impact of the Kempton Park constitution making process, and that served the DP's interests)(footnotes omitted). Klug, note 81, p. 71.

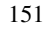

See Spitz/ Chaskalson, note 76, p. 78, 415 (stating that under the agreement, "The ANC would have the assurance that the final constitution would be drafted by a democratically elected Constitutional Assembly, but the freedom of that body would be limited by the framework of justiciable principles agreed at Kempton Park.")

152 CKRC Report, note 118, p. 62 and Committee of Experts, note 133, p. 6-7 (Apr. 4, 2011), http://www.coekenya.go.ke 
and parties were often defended in terms of these principles, even if such were perverted arguments. In the second phase, on a number of issues, the Committee of Experts rejected proposals by the Parliamentary Select Committee to amend the draft Constitution.

The pre-programming of a normative framework for a new constitutional order is uncommon in comparative constitution making. Was this a form of pre-commitment, and if so, whose pre-commitment? Put differently, who were the principals mandating the constitutional/normative principles? In South Africa, although it is not extravagant to claim that these principles were premised on the values over which the natiuon's struggle had been founded, ${ }^{153}$ it may as well be stated that the constitutional principles represented a pact between, and therefore a pre-commitment by, the contending political elites. ${ }^{154}$ They thus only represented a pact in law, ${ }^{155}$ binding on South Africans and the constitution makers. ${ }^{156}$ They were not the direct offering of the people, and some of these principles were adopted "to protect sectional interests."157

This raises two issues which require further inquiry. The first is that such principles do not in themselves invoke a veil of ignorance, which constitutional design theorists have long posited as an important condition under which constitutional choices are made without regard to the benefits and costs to the constitution makers. ${ }^{158}$ The second relates to the limits of public participation and the appropriation of the people's constituent power by elites, such as the drawing of the constitutional principles in South Africa and the normative principles in Kenya. However, it remains an open question whether this makes constitutional pre-commitment undemocratic, if the subsequent constitution making process or constitution acquires democratic credentials and attains legitimacy.

153

See for example, Klug, note 81, p. 22- 24, Ebrahim, note 76, p. 223 and Spitz/ Chaskalson, note 76, p. 83 (stating that the Principles may be traced to the ANC's Constitutional Guidelines for a Democratic South Africa published in 1988, as well as the CODESA talks, the latter venue in which there had emerged a set of principles, signaling convergence on the fundamental pillars of a new constitutional order)

154

Klug, note 81, p. 272. The story is often told of the chemistry between Cyril Ramaphosa and Rolf Meyer, the two lead negotiators of the ANC and the NP, which led to the sealing of agreement on many of the issues. See for example, Patti Waldmeir, Anatomy of a Miracle: The End of Apartheid and the Birth of the New South Africa, New York 1997, p. 208- 214.

The preamble stated that they constituted a record of a solemn pact. See Preamble, Interim Constitution of South Africa (Act 200 of 1993).

156 See Corder, note 91, p. 515-6 (stating that "[t]hese Principles thus function as an external control over the Constituent Assembly, seen by some as testimony to the undemocratic past... [The] Principles ... represent the 'political contract' for the transfer of power from those who held it to those who were excluded. They comprise the framework, the skeleton of South Africa's final constitution...")

157 Spitz/Chaskalson, note 76, p. 79.

158 See generally Adrian Vermeule, Veil of Ignorance Rules in Constitutional Law, Yale Law Journal (2001), p. 399. For a critique, see Arato, note 9, p. 223- 230. 


\section{Transitional Constitutionalism as Pre-commitment?}

An important aspect of South Africa's democratization was its transitional constitution, negotiated by a Multi-party Negotiating Process, ${ }^{159}$ a forum that included other political parties, organizations and administrations under the 'grip' of the ANC and the NP/Government. ${ }^{160}$ The Interim Constitution, ${ }^{161}$ adopted by the MPNP in November 1993 and enacted by Parliament in December 1993, aimed as a bridge between the old order and the new. ${ }^{162}$ Its functions were as follows. First, it housed the procedures and binding constitutional principles with which the new constitution, to be drafted and adopted by an elected Constitutional Assembly, had to comply with. ${ }^{163}$ Second, it represented a clean break from South Africa's past constitutions, pending the final constitution making process. It sought to "civilize the state" 164 and repudiate "the lawlessness of apartheid law." 165 Second, it was a temporal solution to the disagreements on constitutional change. ${ }^{166}$ The delineated stages including deadlock-breaking mechanisms in the Interim Constitution were thus a compromise between the ANC's calls for a swift power transfer and the incumbent's demand for structural guarantees and long-term influence in the constitution making process. ${ }^{167}$ Third, the Interim Constitution underscored the immediacy of human rights, by providing equal rights in the intervening period before the final constitution. ${ }^{168}$ It also

Klug, note 81, p. 23 (stating that the process was under the control of the negotiating parties), Spitz/ Chaskalson, note 76, pp. 37, 4, 43 and 53 (describing, for example, the agreement on the system of proportional and the date of elections, that is, 27 April 1994).

161 Republic of South Africa, Constitution Act (200 of 1993), hereinafter, Interim Constitution.

The postamble to the Interim Constitution provided that: "This Constitution provides a historic bridge between the past of a deeply divided society characterized by strife, conflict, untold suffering and injustice, and a future founded on the recognition of human rights, democracy and peaceful co-existence and development opportunities for all South Africans, irrespective of colour, race, class, belief or sex."

Section 68(2) of the Interim Constitution.

Skjelten, note 76, p. 26.

Skjelten, note 76, p. 15.

166 See generally Jackson, note 12, p. 1252, 1270 (explaining that "transitional" constitutions may seem to offer important solutions.")

167 Klug, note 81, p. 272, (stating that each of the parties sought a constitution making process, "framed in each case by the party's substantive goals."), Kriegler, note 108, p. 362 (explaining that the "existing regime was not prepared to relinquish power and give such a constituent assembly carte blanche...The solution was ...to draw on common practice in complex corporate mergers, where the agreed principles of the merger are recorded up front but the detail is left to be filled in later"), Spitz/ Chaskalson, note 76, p. 69 and Sparks, note 76, p. 12 (Stating that the State 168 President had stated: "Do not expect me to negotiate myself out of power.")

van Wyk, note 6 (discussing among others the repeal or amendment of apartheid era oppressive legislation). 
performed the function of deescalating violence and guaranteeing stability. ${ }^{169}$ Finally, and more paradoxically, the Interim Constitution was the medium for constitutional continuity since the NP/Government had insisted on constitutional change within constitutional confines. 170

In South Africa, there is a more fundamental role played by the Interim Constitution from a pre-commitment perspective: that of entrenching binding constitutional principles with which the new constitution, to be drafted and adopted by an elected Constitutional Assembly, had to comply with. ${ }^{171}$ Even more, the Interim Constitution became a form of transitional constitutionalism, ${ }^{172}$ a detailed constitutional instrument capable of enforcement and interpretation. Normatively, it had a Bill of Rights, whereas institutionally, it enshrined checks and balances, establishing a Constitutional Court and other institutions to support democratic enlargement. It also facilitated South Africa's first democratic elections held in April 1994. In essence, therefore, the Interim Constitution not only symbolized South Africa's journey into constitutionalism, but also became a forum for weaning its polity into a new constitutional diet.

There is a contrasting failure of transitional constitutionalism in Kenya. Although Kenya had no interim constitution antecedent to its new constitution, preceding constitutional reforms among them the reintroduction of pluralist politics, and later the National Peace Accord, ${ }^{173}$ provided a fertile ground for an embryonic or incremental form of constitutional adaptation. ${ }^{174}$ However, these minimum changes were instead used by the ruling party to substitute immediate constitutional change and dilute or divert the agitation for fundamental reform. ${ }^{175}$ It is perhaps fair to note that notwithstanding their impotence as a

Ebrahim, note 76, p. 149- 176.

Klug, note 81, p. 273 (stating that legal continuity was a surrogate for evading a democratically elected constitution making body. He also states further that the NP/Government went so far as to maintain that not even a non-racial election would be held until a new constitution provided a legal basis for universal suffrage) and Spitz/ Chaskalson, note 76, p. 70.

Section 68(2) of the Interim Constitution.

172 See Ruti Teitel, Transitional Justice, Oxford 2000.

173 For a review of the context of the Accord, see Nic Cheeseman /Blessing-Miles Tendi, Powersharing in comparative perspective: the dynamics of 'unity government in Kenya and Zimbabwe, Journal of Modern African Studies (2010), p. 203.

174 This claim may be supported by theories of incremental constitutional change, which posit that there can be fundamental constitutional change through adaptation and minimum reforms where there are political setbacks or legal obstacles to comprehensive or textual constitutional reforms. See Hanna Lerner, Constitution-writing in Deeply Divided Societies: The Incrementalist Approach, Nations and Nationalism 16 (2010), p. 68-88. See also Vicki Jackson/Mark Tushnet, Comparative Constitutional Law (2nd edn.), New York 2006, p. 354.

175 Constitution of Kenya Amendment Act (No. 9 of 1997), The Statute Law (Repeal and Miscellaneous Amendments) Act, 1997 amended the Public Order Act (Cap 56) Laws of Kenya (by removing restrictions on public meetings), the Penal Code (Cap 63) Laws of Kenya (by reforming sedition laws) and the Kenya Broadcasting Act (Cap 221) Laws of Kenya (by requiring equal 
site for transitional constitutionalism, these reforms played a signaling function on the inevitability of fundamental change. Second, the reforms placed the agenda of fundamental constitutional change after the elections in 1997. Moreover, although the political elites demobilized civil society by hijacking the debate, the reform discourse became a permanent fixture of politics from then on. Third, through the accumulated social capital by civil society, this group became a key stakeholder in the constitutional reform process, advancing alternatives to political elite preferences.

\section{Enforcement of Pre-commitment through Constitutional Courts}

Although courts of law play a role in constitutional development through interpretation and constitutional review, they almost have no role in standard forms of fundamental constitution making. ${ }^{176}$ In South Africa, recourse to the Constitutional Court established by the Interim Constitution was a response in part to the vexing question of how to manage the pathologies of constitution makers. ${ }^{177}$ Constitutional principles had been identified as the solution, but the question remained how to ensure that the Constitutional Assembly worked under the shadow of these precepts. A judicial enforcement mechanism became one easy, but contested option. A continuation of the skirmishes over the process of constitution making, the contests were not without merit. It was claimed that the enlisting of the courts would undermine the principle of separation of powers, whereas advocates for the court averred that only the judicial process would ensure compliance with the norms. ${ }^{178}$ Also arraigned in opposition was the claim that the Court, an unelected institution, would circumscribe the powers of a democratically mandated constitution making body, and thus curb majority rule. ${ }^{179}$ Yet some claimed that certification by the Constitutional Court would provide a testing ground in anticipation of the new order. ${ }^{180}$ This would then signal

coverage of all political parties by the state owned media outlet). See generally Stephen N. Ndegwa, The Incomplete Transition: The Constitutional and Electoral Context in Kenya, Africa Today 45 (1998), p. 203 and Frank Holmquist/Michael Ford, Kenyan Politics: Toward a Second Transition? Africa Today 45 (1998), p. 236.

176 Jackson, note 12, p. 1295 (describing the use of courts as “" independent” elements to secure the guarantees of an interim or permanent constitution may also have an important role to play in deeply polarized settings") and Ebrahim, note 76, p. 223.

Kriegler, note 107, p. 362 (explaining that following agreement that a set of principles with which the new constitution would have to comply would be drawn, the question of who would decide whether the constitution drafted by the constituent assembly was in compliance with the stated Principles. The solution, he states, was found in a Constitutional Court, which would be "a new, 178 politically untainted and manifestly independent body.")

Id.

${ }^{179} \mathrm{Id}$.

${ }^{180}$ See Spitz/Chaskalson, note 76, p. 79-80. 
that the South African judiciary had embraced change, and exorcised the ghosts of apartheid "from the top downwards.", 181

Further dilemmas were as follows. First, the ambiguity of the constitutional principles meant that many interpretations on any single issue or an infinite number of texts could pass judgment. ${ }^{182}$ Yet the Court's interpretation on a contested matter could potentially lead to accusations or perceptions of bias towards one among many interpretations. Second, the adoption of the text of the constitution by an overwhelming majority could complicate the Court's work; how could the Court overturn the outcome of a majority? ${ }^{183}$ Third, could the Court entertain objectors seeking to resuscitate political questions on which they had lost rightfully, perhaps not fairly at the negotiations in the Constitutional Assembly? Would its decision amount to reopening these issues?

These conundrums notwithstanding, the Interim Constitution of South Africa mandated the Constitutional Court to act as an independent guarantor, by certifying that the final constitution drafted by the Constitutional Assembly complied with the constitutional principles agreed to by the parties. The Interim Constitution was vague on how such certification would be undertaken by the Constitutional Court. ${ }^{184}$ When the text of the constitution was sent to the Court in May 1996 by the Constitutional Assembly, ${ }^{185}$ five political parties, and a further eighty four private parties subsequently lodged objections on the certification. ${ }^{186}$ Aware of these debates, the Court navigated its course with a "nuanced and politically sensitive response," devoid of technicality. ${ }^{187}$ In its ruling of September 1996, the Court found that the text adopted in May 1996 did not comply with the constitutional principles in some respects, ${ }^{188}$ and referred it back to the Constitutional Assembly. It may have been expected that inter-branch wars would ensue thereafter, but instead, the Consti-

181

182 Stu Woolman/Jonathan Swanepoel, Constitutional History, in: Stu Woolman et al (eds.), Consti183 tutional Law of South Africa Volume 1 (2nd edn.), Cape Town 2009, p. 43.

Ebrahim, note 76, p. 224 and Gloppen, note 76, p. 210- 212.

Denis Davis/Michael Chaskalson, Constitutionalism, the Rule of Law, and the first Certification, South African Journal on Human Rights 13 (1997), p. 430.

Following the elections of April 1994, the Constitutional Assembly was constituted by the National Assembly and the Senate, the two legislative chambers under the Interim Constitution in May 1994. Chaired by a member of the ANC, the Constitutional Assembly comprised 490 members, representing seven political parties. See Klug, note 81, p. 51 and Ebrahim, note 76, p. 5.

Ex Parte Chairperson of the Constitutional Assembly: In re Certification of the Constitution of the Republic of South Africa 1996 (4) SA 744 (CC), 1996 (10) BCLR 1253.

187

Woolman/Swanepoel, note 182, p. 43 and Ebrahim, note 76, p. 225.

188

Albie Sachs, Creation of South Africa's Constitution, New York Law School Law Review (19961997), p. 669. 
tutional Assembly revised the text, and having adopted it by an overwhelming majority, referred it back to Court, which certified it promptly in December $1996{ }^{189}$

The agreement to vest the Court with such powers was particularly significant given the legacy of judicial subservience during the apartheid era. Despite its putative undemocratic nature, this enterprise also turned out to be the inauguration of constitutionalism and democracy under South Africa's new political order. ${ }^{190}$ In the certification process, for example, the Court invited submissions from all parties in the Constitutional Assembly as well as the public. ${ }^{191}$ In upholding the Constitutional Principles, the Court signaled the significance of pre-commitment in constraining governmental power under the new constitutional order. In hindsight, the delay occasioned by the Court's refusal also provided the Constitutional Assembly with the opportunity to correct the defects in the text and seek a return of one of the parties which had walked out of the negotiations, the IFP. ${ }^{192}$ Based on the issues on which the Court had based its rejection of the first text, the certification led to a "vast improvement of the old text." 193 It also appears, given that the National Party was among the objectors, that the Court played the role that the parties had foreseen, that is, enforcing their pre-commitments.

Constitution making in Kenya provides mixed insights on the role of courts. In the second phase of constitution making between 2008 and 2010, an Interim Independent Constitutional Dispute Resolution Court was established through a constitutional amendment, with exclusive original jurisdiction to hear and determine all and only matters arising from the constitution making process. ${ }^{194}$ Comprising nine judges, three of whom were foreign nationals nominated by an independent process, this Court was intended to oust the jurisdiction of the High Court, the repository of constitutional interpretation in Kenya. ${ }^{195}$ The Interim Court was established as a special institution, independent of the mainstream

Ex Parte Chairperson of the Constitutional Assembly: In re Certification of the Amended Text of

190 Ebrahim, supra note 76 at p. 226 (stating that the Court's refusal to certify in the first instance the Constitution of the Republic of South Africa 1997(2) SA 97 (CC), 1997 (1) BCLR 1. was "hailed as a victory for constitutional democracy.")

191 Yvonne Mokgoro, Constitutional Courts in Constitution Making and the Constitutional Process: The South African Case, Judiciary Watch Report 10 (2010), p. 330.

Ebrahim, note 76, p. 226.

193 Ebrahim, note 76, p. 231. See also Woolman/Swanepoel, note 182, p. 45 (stating that the rejected provisions, "to a greater extent, interfered with or threatened to interfere with institutions and mechanisms designed to protect the rule of law and the project of con democracy" and as such the certification process enabled the rectification of these defects).

Section 60A of the Constitution of Kenya (Revised Edition 2009).

195 Section 60 of the Constitution of Kenya (Revised Edition 2001). In order to circumvent the ouster of the High Court's jurisdiction, some parties alleged violations of their fundamental rights in the constitution making process, but the Court refrained from entertaining such cases. 
judiciary. ${ }^{196}$ Its decisions were final, and not subject to review or appeal before the High Court or Court of Appeal, the latter until then Kenya's apex judicial court.

The Interim Constitutional Court had its origins in vexatious litigation and resort to the courts in lieu of negotiations by different actors during the first phase of constitution making between 2000 and 2005. In this phase, the courts of law were used to challenge, sometimes obstruct the process. A number of cases were filed under the public interest veneer, with claims relating to legality of the constitution making process, but their leitmotif was to frame contested political questions within the courts or to disrupt the tight timetable for the drafting of the Constitution. It was claimed that a number of the cases were instituted at the behest of the political elites ambivalent to fundamental constitutional change. ${ }^{197}$ In the period, there are at least eight cases, a few of which stand out in particular. $^{198}$

The first of these was a case filed by two judges of the High Court and Court of Appeal in August 2002, ${ }^{199}$ seeking to enjoin the Constitution Review Commission from adopting provisions that would alter the structure of the judiciary or adversely affect the judges' tenure of office. This case claimed a carve-out of the judiciary from the institutional reforms envisaged in the constitution making process. Yet the decline of the judiciary had been one of the impulses for constitutional change, ${ }^{200}$ and the Commission was mandated specifically to examine ways and means of judicial reform in the Review Act. Subsequent cases were particularly determinative of the course, perhaps ultimate failure of the first phase of constitution making. In the Timothy Njoya $v$ CKRC case, ${ }^{201}$ filed towards the end of the National Constitutional Conference in the first quarter of 2004, the applicants claimed that the statutory procedure requiring the enactment of the Draft Constitution by Parliament was unconstitutional, as it usurped the people's sovereign right to make their constitution. Despite the absence of any textual basis, the High Court was further petitioned to determine whether a constitutional referendum was required so as to enable the people to exercise their inherent constituent power through ratifying the new constitution. In its Cottrell/Ghai, supra note 100, p. 13.

See CKRC Report, note 118, p. 472. See also Kithure Kindiki, The Emerging Jurisprudence on Kenya's Constitutional Review Law, Kenya Law Review 1 (2007), p. 153. It is notable that the Patrick Onyango Case is an outlier in this regard. See also Cottrell/Ghai, note 100, p. 18 and Law 199 Society of Kenya, note 128. Judges' case, supra note 208.

Republic of Kenya, Final Report of the Task Force on Judicial Reforms, Nairobi 2010 and Dan Juma, The Normative Foundations of the New Constitution of Kenya: The Judiciary Past, Present and Future, Judiciary Watch 10 (2010), p. 215.

Timothy Njoya \& Others $v$ CKRC and the National Constitutional Conference, High Court Misc. Application No. 82 of 2004 (Apr. 4, 2011), http://www/kenyalaw.org 
ruling, the Court declared that the people of Kenya were entitled to a referendum on any proposed new constitution as of right.

It appears that this decision was essentially a tutorial on how to structure constitution making, with an edict that a referendum was a prerequisite to legal validity, perhaps legitimacy. ${ }^{202}$ However, this interpretation was problematic, since the Constitution did not expressly mandate a referendum, whereas it could be maintained that constitutional legitimacy does not vest in a referendum per se but instead other norms including internalization and social acceptance. ${ }^{203}$ The decision's other burden is that it appeared to track an earlier proposal by one faction of the government - which had insisted on a referendum thereby raising questions whether it was outcome-oriented in favor of this group. ${ }^{204}$ Quite apart from its merits and rhetoric, this ruling paved way for a raft of amendments to the legal framework for constitution making, thereby vesting Parliament with plenary power to amend the Draft Constitution adopted at the National Constitutional Conference. The last of these cases was an application brought in the first half of 2005 challenging the legality of parliamentary amendment of the Draft Constitution adopted by the National Constitutional Conference and the constitutionality of the referendum. ${ }^{205}$ In its decision of November 2005, the High Court held that the process, including the referendum, was constitutional, it had "no authority to stop the adoption or rejection at a referendum of a constitutional proposals on the basis that one on the other of the draft proposals were altered or mutilated., 206

The essence of this judgment was the Court's reading of a referendum right into the constitutional text, in the absence of an express provision of such entitlement. This approach was opposed by Justice Benjamin Kubo, who took the view that a referendum was not a mandatory constitution making procedure, nor was it the only way of exercising the constituent power of the people. He observed that it was not expressly provided for in the Constitution of Kenya, and therefore could not be deemed to be requisite. See generally Kindiki, note 198, James T. Gathii, Popular Authorship and Constitution-making: Comparing and Contrasting the DRC and Kenya, William \& Mary Law Review 49 (2008), p. 1125 and H.W. O. Okoth-Ogendo, The Referendum as an Instrument of Decision Making, in: Constitution of Kenya Review Commission, Report of the Constitution of Kenya Review Commission (Volume 5), Nairobi 2005, p. 158.

See generally Michelman, note 19.

See Cottrell/Ghai, note 100, p. 17 (stating that this case "was instituted to stop the work of the NCC and prevent Parliament from enacting the Draft Constitution adopted by the NCC. It was also aimed at requiring a referendum on the proposed constitution. It was assumed to have been brought with the backing of government and it did not go unremarked in the media that the presiding judge (Justice Ringera) was in line for a major post). See also Njuguna Michael Kung'u, Gacuru wa Karenge \& Nichasius Mugo v the Republic, Attorney General and CKRC, High Court Misc. Application No. 309 of 2004 (Apr. 4, 2011), http://www/kenyalaw.org (which similarly, case claimed that the adoption of the Draft Constitution by the National Constitutional Conference in March 2004 was ultra vires the procedures laid out in the Review Act.)

Ibid. 
The contradictions and ambiguities inherent in these cases bespeak a crisis of constitutional interpretation and dubious constitutional theorizing during this period, as well as the limits of popular constitutionalism in constitutional ordering. ${ }^{207}$ The Timothy Njoya case, for example, claimed a constitutional recovery of the people's constituent power, but also opened the gates for a revocation of the right through a series of amendments to the Review Act. The Patrick Onyango case reaffirmed its predecessor, but instead claimed that Parliament could essentially abrogate this right by amending the Draft Constitution without any constraints, before submitting such outcome to a referendum. This decision was considered by some as a departure from the pronouncements in the earlier case of Timothy Njoya discussed above. Here as in the other cases, it was claimed that the government controlled the outcome. According to the former head of the Review Commission, the government "believed that they would win the referendum, [so] it gave the go-ahead to the courts to decide it." 208

Second, these courts claimed that their jurisdiction did not extend to political questions, although in reality, their decisions implicated not only legal but also political issues. The Patrick Onyango Court's characterization that the penultimate stage of constitution making was a consultative stage in which amendments could be made to the Draft Constitution was particularly fatal, since it paved the way for the submission of a contentious Draft Constitution to the referendum vote. These judicial cases also made political settlement implausible, since parties sought to use them in lieu of direct talks. This was not lost to the chairperson of the National Constitutional Conference, who, instead of adjourning the talks following the government walk-out so as to deescalate the situation, opted to accelerate the adoption of the Draft Constitution in March 2004, fearing obstruction by cases the following day. ${ }^{209}$ It is this checkered background that formed the basis of Kenya's Interim Constitutional Court; an antidote, intended to oust the High Court from determining questions relating to constitution making.

Kenya's Interim Constitutional Court however contrasted with South Africa's Constitutional Court. As its name suggests, the former was conceived to be a dispute resolution forum, complementary to the other inbuilt mechanisms in the constitution making process. It had no substantive mandate to prefer any of the set of proposals or drafts, implicit in the

See Gathii, note 202, p. $1127-1130$ (noting that the framing of the debate in a number of the cases was in part "informed by the narrow question regarding "where to locate agency or legal title to make the [new] constitution legally binding" and that the courts proceeded from the premise that "Kenya's ultimate rule of recognition for its constitutional order was based on another rule...yet tracing the validity of one constitution to another ignores whether the preexisting, or indeed newly drafted, constitution has legitimacy or efficacy").

209 See Cottrell/Ghai, note 100, p. 16 (explaining that "[o]ne reason for some sense of haste in the final stages was a suspicion that some more mischief was brewing in the form of litigation. And indeed that was so, and a convenient court order prevented the CKRC from passing its report and the draft constitution to the attorney-general.") 
South African Constitutional Court's certification process. The Interim Constitutional Court therefore adopted a purely judicial approach in its procedures, and only legal issues relating to the process of constitution making were admissible. ${ }^{210}$ It appears that like its South African counterpart, the Court also determined and disposed its cases with political adroitness, paving way for the conduct of the referendum, and promulgation of the new Constitution of Kenya within the default timeframe.

\section{Conclusion}

It has been remarked that constitution making is perhaps the most sacred of all secular tasks. ${ }^{211}$ However, constitution making can also be the antithesis of constitutionalism. This paper deployed an analytical and descriptive approach to examine the paradoxes of constitution making, and whether constitutional pre-commitment can be used as a check on the pathologies of fundamental constitutional change. The overall conclusion is that it is plausible to exert pre-commitment devices in constitution making. But this constitutional imaginary is not without qualification. Constitution making procedures and experiences are by no means generalizable, and as such it cannot be claimed that pre-commitment devices in the South African or Kenyan constitution making processes provide conclusive models for taming constitution makers elsewhere. It also safe to conclude that both cases of constitution making in South Africa and Kenya illustrate that pre-commitment is itself beset by challenges. Pre-commitment may be used to advance partisan interests, thus replicating the problems it seeks to remedy. Another problem regarding pre-commitment in constitution making is the challenge of limited public participation in the institution of such devices. The earlier stages of the negotiations and the grip of the NP/Government and the ANC on the constitutional negotiations in South Africa, as well as the Kenyan experience, particularly demonstrated these limits. But there is a more problematic issue, which relates to how parties may enter into pre-commitment in constitution making processes, where getting to the table and agreeing is not as 'easy' as was in South Africa and Kenya. It is however not the burden of this paper to speculate on how to deal with these problems, and herein lies the agenda for further research.

The second conclusion is that quite apart from the utility of pre-commitment devices as constraints on constitution makers, other determining factors are often at play. Thus the success of the constitution making processes in South Africa may as well be attributed to the restraint of the actors themselves, due to considerations other than pre-commitment. But there is a more vexing question that pre-commitment does not in itself insure any specific normative outcomes. The paper therefore concludes that other analytics should be explored in exploring these conundrums, with a view to finding better solutions.

210

Republic of Kenya, Interim Independent Constitutional Dispute Resolution Rules of Procedure, Nairobi 2010.

211

Yash Ghai, Address to the National Constitutional Conference, Plenary Report (May 6, 2003). 